\title{
Examining Trade by Destination, Innovation and Human Development in FOCAC
}

\author{
Elias Ellias Tsokalida, Jun Yang* \\ School of International Trade and Economics, University of International Business and Economics, Beijing, China \\ Email: etsokalida@yahoo.com, *yangjunuibe@163.com
}

How to cite this paper: Tsokalida, E.E. and Yang, J. (2019) Examining Trade by Destination, Innovation and Human Development in FOCAC. Open Journal of Business and Management, 7, 1225-1243. https://doi.org/10.4236/ojbm.2019.73086

Received: June 3, 2019

Accepted: July 7, 2019

Published: July 10, 2019

Copyright $\odot 2019$ by author(s) and Scientific Research Publishing Inc. This work is licensed under the Creative Commons Attribution International License (CC BY 4.0).

http://creativecommons.org/licenses/by/4.0/

cc) (i) Open Access

\begin{abstract}
There are few empirical research papers on the impact of trade by destination on human development, most of which focus on the direct impacts completely ignoring the indirect impacts through various channels. The main objective of this paper was to examine the impact of trade by destination towards strategic partners on human development through innovation channel captured using capital imports, while controlling for endogenous impacts from economic growth and at the same time providing new evidence on the direct impacts. This study was demonstrated using a sample of 40 Sub Saharan African countries (SSACs) and their trade partnership with China under the Forum for China-Africa Cooperation (FOCAC) framework for the period from 2000 to 2017. To avoid bias, the study controlled for other SSACs trade partners using rest of world trade patterns. The framework was estimated using two simultaneous equation generalized methods of moments (GMM) for economic growth and human development and also considering that trade and innovation can impact both economic growth and human development. The results indicated that both SSACs trade openness towards China and SSACs trade openness towards rest of world, had positive and significant impacts on human development at $1 \%$ level. The study also found that innovation from China and innovation from rest of world had both negative and insignificant impacts on human development. The results were robust to simultaneous equation three stages least squares (3SLS) and single equation two-step GMM. The study also found comparable results when time period was extended from 1990 to 2017 and innovation was instead captured using total capital trade. These findings suggest that trade partnerships matter for enabling potential gains from trade openness on human development and to maximize such gains, SSACs need to reform and incorporate human development aspects in their key policies including innovation as these create a conducive environment through which trade impacts can be sustainable and inclusive.
\end{abstract}




\section{Keywords}

Human Development, Innovation, Economic Growth, Capital Imports, Trade, FOCAC

\section{Introduction}

One of the less investigated areas in empirical economic literature is the relationship between trade openness by destination and human development. There are very few studies on the impact of trade openness by destination on human development and among the few, focus is on the direct impacts of trade openness on human development. Among these few, the results are also different depending on the countries included in their sample, the length of period, the methodologies used as well as the key indicators for trade openness and human development. Most of the studies used aggregate trade openness towards the whole world and human development index as a proxy for human development. Most existing empirical literature ignored the indirect impacts through various channels.

Trade openness and human development are interlinked and the channels of impact can either be direct or indirect. The main objective of this research was to examine the impact of trade openness by destination trade partners on human development through innovation channel while at the same time providing new evidence for the direct impacts of trade openness by destination on human development. This study was demonstrated using the Forum for China-Africa Cooperation (FOCAC) framework for the period from 2000 to 2017. The African sample only contains Sub Saharan African countries (SSACs). The rest of SSACs trade partnerships are controlled using rest of world variable. Much as there are a number of channels through which the impact of trade by destination can be channeled towards human development, this paper pays particular focus on innovation while at the same time controlling for the endogenous impacts of economic growth. In so doing, this study examined this framework using a system of two simultaneous equations by employing the multiple equation generalized method of moments (GMM) for the two separate equations for economic growth and human development.

Trade openness represents a key element as well as a necessary framework for achievement of both economic growth and human development [1]. As a region, the SSACs started implementing trade openness reforms following the failure of import substitution policies which were implemented between 1970s and 1980s. Most SSACs had already been engaged on a roadmap towards trade openness in early 1990s in line with structural adjustment programs (SAPs) of the World Bank in order to jumpstart their stagnant economies by creating a more economic growth conducive environment. [2] noted roughly about 700 million to 1 billion people (representing roughly between $10 \%$ to $15 \%$ ) of the world's 6.5 billion people of which 5.3 billion in developing countries are poor and live their 
life on no more than US\$1 per day making human development a key focus.

Trade openness and human development are interlinked in the sense that trade openness can play an instrumental role in improving human development of countries. However, the links between trade openness and human development are not automatic and, in some cases, they are complex. The impacts of trade openness on human development can either be direct or through various channels. [3] cited four pillars through which trade can impact human development namely: equity and equality; sustainability; empowerment; and productivity growth. Equity is more related to the principles of natural justice and fair conduct whereas equality on the other hand concerns equal opportunity, rights, privileges and status. Initial improved conditions in both equity and equality means that trade reforms have potential to benefit wide groups of people. Sustainability concerns the length of period that benefits from trade reforms will last so that future generations must also benefit. This is dependent on complimentary and supporting policies such as institutions, technology and innovation levels, and to some extent geographical factors such as landlockeness. Empowerment mainly concerns enabling individuals in societies to have free choice and to have a conducive participatory environment in human development processes. Most important is an increase in income which allows individuals to have access to better services. Whereas productivity concerns the fundamental role that an improvement in human capabilities plays in facilitating effective participation of individuals in economic growth through improvements in health, education, incomes or technology and innovation.

[1] noted that the impact of trade openness on living standards of people is transmitted through enterprise (employment levels), distributional (price level or inflation), economic growth and government revenue. Trade openness may lead to an influx of foreign firms which may in-turn employ more people, thereby increasing employment levels. In other cases, trade openness may increase the inflow of imports into a country thereby reducing the prices of available goods. In other cases, trade openness may lead to a loss of government revenue as countries remove tariff and non-tariff barriers. However, the benefits would set-in depending on what policies and strategies particular governments have in place that would raise revenue from other sectors and allocate them to sectors previous financed from tariff revenue. [4] argued that free trade must be welfare enhancing and if not, a country may choose to continue in autarky. [5] and [6] argued that there are both winners and losers of trade openness. [1] and [3] both agree that the sustainability of the benefits from trade openness depends to a larger extent on the complementary and supporting domestic factors prevailing in a country. [7] and [8] highlighted the role of institutions while [9] [10] and [11] emphasize the key role of technology and innovation in fostering human development. This research focusses on innovation channel while controlling for the direct effects of institutions. This research seeks to examine whether the level of innovation in respective SSACs coupled with enhanced trade integration improves human development. [12] defines innovation as the implementation of a new or significantly 
improved good or service or processes. [13] emphasized that innovation refers to those technologies or practices that are new and being diffused in a given society, which may not necessarily be brand new in absolute terms.

Countries all over the world have embraced innovation as an important channel for accelerating human development. Innovative economies are more productive, more resilient, more adaptable to change and better able to support higher living standards. Strengthening innovation is therefore a fundamental for countries in their quest for greater prosperity and better lives. Trade offers a great opportunity for enhancing the transfer of technology which when harnessed eventually leads to inclusive innovation which improves human development. Greater imports offer consumers a wider variety of goods at lower prices, while providing a cheap source of technology and innovation used in production processes for producers. In this research, innovation is measured total capital imports as a ratio to gross domestic product (GDP). In the competitive global economy, innovation is essential for achieving country-level economic development. An innovation-focused economy builds capacity for a nation to develop and export higher-value products, use resources more efficiently, and create wealth domestically.

This paper makes three main contributions. Firstly, FOCAC is considered one of the vital partnerships on both the African and China side. However, empirical literature on the partnership is very limited. Secondly this paper contributes to empirical literature on the impacts of trade openness on human development. Existing research has only focused on the direct impacts of trade openness on human development and has treated trade openness as an aggregate indicator towards the whole world. Existing literature on the direct impacts has also produced mixed results thereby providing more room for new research. This paper differs from existing research in the sense that trade openness has been created towards destination trade partnership as well as capturing both the indirect and direct channels of impacts. Our third contribution comes from the second equation on the impacts of trade openness by destination on economic growth. Up to now, existing empirical literature on this relationship between trade openness is still mixed and inconclusive. Other studies found positive results (e.g. [14] and [15]) while others found negative when geography and institutions were included (e.g. [16]). Other studies doubted the causal relationship between trade openness indicators and economic growth as most indicators of trade openness lacked theoretical backing and, in some cases, captured other policies other than trade policies (e.g. [17] and [18]). The remainder is as follows: Section 2 presents the literature review; Section 3 is about the research methodology; Sections 4 provides our results and discussions of findings and Section 5 provides a conclusion.

\section{Literature Review}

\subsection{Evolution of the China-Africa Partnership}

Modern Africa-China contacts can be traced to the founding of the People's Republic of China in 1949 and the Bandung conference which was held in 1955 in 
Indonesia, where participants from Egypt, Ethiopia, Ghana, Liberia, Libya, Sudan and China were present. Later on, China incorporated in its foreign policy, the China-Africa policy, focusing on establishing diplomatic ties and strengthening trade, aid and investment. As African countries were rapidly gaining their independence, they had a strong desire for international cooperation to further achieve their socio-economic development. While on China's side, China had just implemented major economic reforms that required an expansion in terms of market for its final products as well as sources for inputs for production (see [19] and [20] for brief background). In 2000, the two sides established FOCAC to provide a framework for equal consultation for enhanced cooperation in many areas including trade [21]. Under this cooperation framework, the two sides agreed to encourage preferential market access especially for products originating from African less developed countries (LDCs) having diplomatic relations with China into Chinese market. China implemented the zero-tariff treatment scheme for imports originating therefrom. By 2018, China progressed with its zero-tariff exemption to products under $97 \%$ of all tariff items from African LDCs having diplomatic relations with China based on rules of origin as well as setting up a US $\$ 5$ billion special fund for financing imports from Africa [22].

Figure 1 provides a summary of trade relations between African countries and China in million US dollars. Trade relations between the two sides grew significantly and in 2008, reached approximately US $\$ 102.8$ billion and eventually China became Africa's largest trading partner [23] and [24]. By the end of 2012, twenty-two (22) Africa LDCs had RMB910 million worth of tariff exempted, involving US $\$ 1.49$ billion-worth of goods [23], [25] and [26]. The two sides are further expected to scale up their trade to US $\$ 400$ billion by 2020 from US $\$ 220$ billion in 2014 [25]. Capital goods imports represent a significant portion of total imports by African countries from China as compared to imports of consumer goods.

\subsection{Review of SSACs Innovation Pattern}

Globally, innovation has been embraced as a key factor determining economic growth and human development. Innovation has transformed living standards with improvements in life expectancy, basic health care, education, and improvements in income and productivity levels [27]. Developing countries in general and SSACs in particular, have an opportunity to benefit from innovation by taking advantage of already existing innovation from developed and other developing countries such as China through capital imports and adapting them to suit their domestic needs. As shown in Figure 1, capital imports by SSACs from China represent an opportunity for SSACs to innovate at a cheaper cost. However, for countries to effectively adopt innovation from other countries, there is need for more investment in supporting structures and institutions. Yet, despite these potentially high returns, most developing countries inclusive of the SSACs invest far less in innovation proportionately than their rich counterparts. 


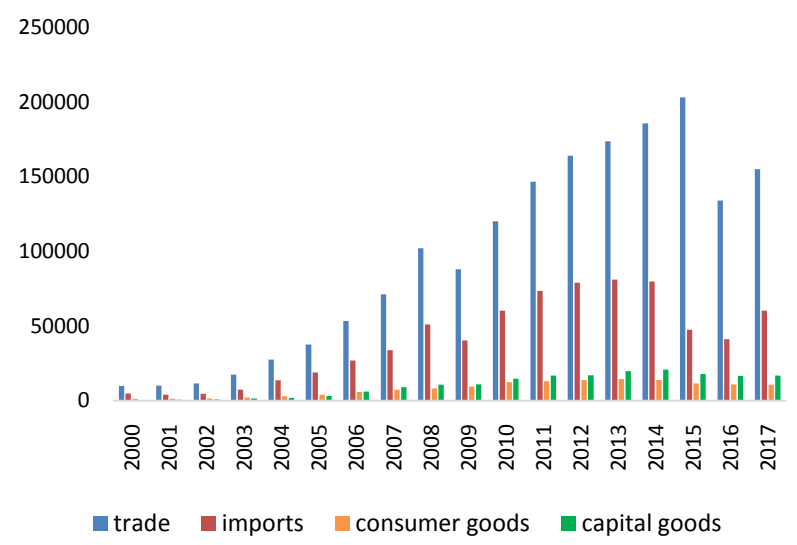

Figure 1. Africa-China trade patterns. Source: prepared by author based on World Bank World Integrated Trade Solutions and National Bureau of Statistics of China.

[28] noted that most SSACs national gross expenditure on research and development is still less than $1 \%$ of GDP despite efforts at the continental level to set $1 \%$ of GDP as a target. In other words, adopting and adapting innovation from other countries is very much dependent on availability of certain factors without which countries cannot realize the enormous promised gains from innovation ([29] and [30]). SSACs are continuously becoming an important test lab for global innovation in a midst of many challenges it faces, to the point that if an innovative product or service originates from Africa, chances are that it will be highly competitive in many other regions. Likely, SSACs innovation mainly originates from the extreme need to find immediate, sustainable solutions for critical problems.

It makes sense for African nations invest in sectors where they have comparative advantage and most SSACs would like to build a strong manufacturing sector. Much of Africa's strong growth over the last two decades has been driven by the production and sale of natural resources as most SSACs are very well endowed in-terms of natural resources. SSACs can do a lot to improve the productivity of these sectors by adapting innovation from other countries such as China, which will eventually help them move higher their value chain. This would mean instead of exporting raw materials, with this innovation productivity, they would start exporting processed products. Thus, SSACs need industrialization to change the structure of their economies, and this to happen would require adopting and adapting innovation from other countries to enhance productivity in key industries.

\subsection{Review of Related Literature}

Most of these studies found positive impact of aggregate trade openness on human development. [31] examined the three-way relationship among trade openness, economic growth and human development, using a sample of 12 developing Asian countries. They used aggregate trade share index while human development was proxied using HDI. They found positive direct impacts of 
trade openness on human development using error correction model. [32] examined the impact of trade and financial globalization on human development using a sample of 52 African countries for a period from 1996 to 2010. They found positive and significant results direct impacts. [33] examined the impact of trade on human development using a sample of 154 countries for a period from 1975 to 2002 using a GMM methodology. The proxied human development using HDI. Their trade openness index was slightly different from the rest of the previous papers by using per capita trade calculated as the natural logarithm of current trade share (total trade as a ratio of current GDP) less the natural log of previous year trade share. They still found positive and significant direct impacts of trade on human development. A more different study was conducted by [34] by examined whether more open economies which have higher economic growth have translated that growth into economic development, for a period from 1970 to 1985 using a sample of 95 developing countries. They measured human development using a variety of four separate human development indicators namely: $H D I$, income distributed adjusted $H D I$, rate of change of the under-five mortality rate, and the level and rate of change of the proportion of the population with access to safe water; and proxied trade openness using purchasing power parity and relative prices openness index. They found positive impacts across all the human development indicators.

Other studies found both positive and negative results when different indicators of trade openness. [35] examined the interaction among openness, growth and development using two simultaneous equation. The found positive impacts of trade openness using trade share. However, they found negative relationship when they used black market premium. [36] examined the impact of trade openness on human development using a sample of 60 countries for the year 2008. The proxied trade openness using trade restrictive index (TRI) constructed using both tariffs and non-tariff barriers (NTBs). The proxied human development uses six human development indicators separately. These include infant mortality rate; child (under-5) mortality rate; maternal mortality rate; access to safe water; access to basic sanitation; and secondary-school enrollment. They found no correlation between trade openness and human development. [37] in their study measured innovation using the number of scientific and technical journal articles published. They found positive impacts.

On the other hand, there is a wide range of literature on the impact of trade openness on economic growth. Most studies on the impact of trade openness on economic growth found positive results ([14] [15] and [38]).

\section{Research Methodology}

\subsection{Data Sources}

Trade data used in construction of trade openness by destination index, and trade in capital goods used in construction of innovation index were all obtained from UNComtrade for the World Bank World Integrated Trade Solutions 
(WITS). GDP per worker (proxy for economic growth); secondary school enrollment (proxy for human capital); government expenditure in primary education (proxy for education); health expenditure as a ratio of GDP (proxy for health); FDI ratio to GDP (proxy for physical capital); official development assistance as ratio of GDP (proxy of aid); total working labor force (proxy for labor); and oil rent as percentage of GDP (proxy for oil producing country); were obtained from World Bank World Development Indicators (WDI). Rule of law and government effectiveness indicators as proxies for institutions were both obtained from World Bank WGI. FOCAC variable was obtained from FOCAC website and one China policy, which was partly used in the construction on FOCAC dummy variable was obtained from Ministry of Foreign Affairs of the People's Republic of China website. Data on HDI were obtained from UNDP database. Landlocked variable was obtained from Centre d'Etudes Prospectives et d'Informations Internationales (CEPII). The time period for this study is from 2000 to 2017 based on availability of data.

\subsection{Human Development Equation}

The human development equation is built along the capabilities approach which views development as a process of expanding human freedoms that allow human individuals to pursue those things that they value [39], [40] and [41]. The final human development equation is presented below as Equation (1).

$$
\begin{aligned}
\ln \text { HDI }_{i, t}= & \beta_{0}+\beta_{1} \ln \text { TOChina }_{i, t}+\beta_{2} \ln \text { TOrow }_{i, t}+\beta_{3} \ln \text { Growth }_{i t} \\
& +\beta_{4} \ln \text { InstitGF }_{i, t}+\beta_{5} \ln \text { Health }_{i, t}+\beta_{6} \ln \text { Education }_{i, t} \\
& +\beta_{7} \ln \text { ARInnov }_{i t}+\beta_{8} \ln \text { AChinainnov }_{i t}+T E+C E+\varepsilon_{i, t}
\end{aligned}
$$

where $H D I$ is human development index, Health is government health expenditure per GDP as health proxy, Education is government spending in primary education as education index, Institut $G F$ is government effectiveness institution index and Growth is economic growth index measured as GDP per worker. Variable TOChina is constructed by interacting FOCAC membership and trade share index between SSACs and China. The trade share index between Africa and China is constructed as total African exports to China sum total African imports from China as a ratio of current GDP. Whereas FOCAC variable took the value of one if year was either 2000 or above and a particular SSAC recognized one China policy. This was necessary because not all SSACs were members of FOCAC since 2000. Membership depended on whether these SSACs established diplomatic ties with China and recognized One China policy. The variable created by interacting FOCAC and SSACs-China trade share is what was referred to as SSACs trade openness towards China. Variable TOrow is trade openness by destination index designed to capture rest of SSACs trade partnerships in order to avoid bias. Variable ARInnov is designed to capture innovation channel originating from rest of world. It is constructed as total capital imports from rest of world by respective SSACs as a ration of GDP. Variable AChinainnov is designed to capture innovation channel from China as is constructed as 
total capital imports from China by respective SSACs as a ratio of respective SSACs GDP. Also included in the model are constant $\beta_{0}$, error term $\varepsilon_{i, t}$ as well as both country fixed effects $(C E)$ and time fixed effects $(T E)$. Subscript $i$ refers to a particular SSAC while subscript $t$ captures time period measured annually.

\subsection{Economic Growth Equation}

The final economic growth model is presented as Equation (2) below:

$$
\begin{aligned}
\ln _{\text {Growth }_{i, t}} & \alpha_{0}+\alpha_{1} \ln \text { TOChina }_{i, t}+\alpha_{2} \ln \text { TOrow }_{i, t}+\alpha_{3} \ln H D I_{i t} \\
& +\alpha_{4} \ln \text { InstitutRL }_{i, t}+\alpha_{5} \text { InAid }_{i, t}+\alpha_{6} \ln H C_{i, t}+\alpha_{7} \ln K_{i, t} \\
& +\alpha_{8} \ln L_{i, t}+\alpha_{9} \ln \text { Oil }_{i, t}+\alpha_{10} \ln \text { LandL }_{i, t}+\alpha_{11} \ln \text { ARInnov }_{i t} \\
& +\alpha_{12} \ln \text { AChinainnov }_{i t}+T E+C E+\varepsilon_{i, t}
\end{aligned}
$$

where $H C$ is human capital index, $K$ is physical capital index, $L$ is labor index, Aid is official aid indicator; InstitutRL is rule of law institutions indicator; $\ln O i l$ is oil rent variable; $\ln L a n d L$ is a dummy variable for landlocked countries taking the value of one if a country is landlocked and zero otherwise; and $\alpha_{0}$ is our constant term. The other variables are defined as in Equation (1).

\subsection{Estimation}

The study builds a two simultaneous equation system in order to control for endogeneity resulting from jointly determined variables especially among trade, economic growth and human development. Empirical literature suggests that the impact of trade on human development can be driven by other variables and channels such as economic growth. Taking into consideration that both economic growth and human development can have their own determinants and in-turn each can be affected by both trade and innovation, this study therefore models a total of two equations for trade, economic growth and human development. That is, we seek to estimate the impact of trade on human development through innovation channel while at the same time controlling for endogenous effects of both trade and economic growth. Simultaneous equation system works best in cases where endogeneity is problematic as it is a fundamental specification property by default (see [42], [43] and [44]). Other addition measures for endogeneity include the use of economic growth rates and lagged values for indicators of health, aid and education.

The final two simultaneous equation system has both Equation (1) and Equation (2) estimated together using multiple equation GMM. Although, our alternative estimation method would have been the three stages least squares (3SLS), multiple equation GMM offers an efficient and consistent way as it is easy to control for heteroscedasticity than 3SLS. Recalling Equation (1) and Equation (2) and letting $Z_{1}$ and $Z_{2}$ denote the instruments of for the two equations, then the two equation GMM would have the following moment condition:

$$
E\left\{\begin{array}{l}
Z_{1}(\text { hdi }-X \beta) \\
Z_{2}(\text { growth }-V \beta)
\end{array}\right\}=0
$$


where for simplicity $X \beta$, and $V \beta$ represent Equations (1) and Equation (2) respectively. Then the full system could be formulated using the general notation as follows:

$$
\left[\begin{array}{l}
y_{1} \\
y_{2}
\end{array}\right]=\left[\begin{array}{cc}
Z_{1} & 0 \\
0 & Z_{2}
\end{array}\right]\left[\begin{array}{l}
\beta_{1} \\
\beta_{2}
\end{array}\right]+\left[\begin{array}{l}
\epsilon_{1} \\
\epsilon_{2}
\end{array}\right]
$$

The $y$ matrix is a $2 \times 1$ matrix of endogenous variables namely human development, economic growth and trade. The $Z$ matrix is the $2 \times 2$ matrix with variables that explain the endogenous variable. In 3SLS, the $Z$ matrix is considered the multivariate analogue of a homoskedasticity assumption where the error variance is constant for all observation as is the covariance between any two equations' error terms. This means 3SLS is consistent but no longer the optimal estimator. This study uses multiple equation GMM but reserves 3SLS for robustness checks. The $\beta$ and the $\epsilon$ matrices are $2 \times 1$ matrices of beta coefficients and error terms, respectively.

\subsection{Summary Statistics}

Table 1 provides a summary of all the variables used in this study. There are 720 observations and 40 SSACs including 14 landlocked countries (Botswana, Burkina Faso, Burundi, Central African Republic, Ethiopia, Lesotho, Malawi, Mali, Niger, Rwanda, eSwatini, Uganda, Zambia and Zimbabwe). Exports and imports are used in the construction of total trade share index towards rest of world whereas world capital imports are used to construct innovation from rest of world. Exports to China, imports from China, and capital imports from China are used in the construction of trade openness towards China and innovation from China, respectively. All trade figures are in millions of US dollars. $H D I$ is a geometric mean of health; education; and living standards [45]. HDI ranges in value between zero for low human development and one for high human development. Variables InsitGF and InstitutRL are governance indicators and range from -2.5 for weak governance and 2.5 for strong governance. InstitGF is among other things concerned with quality of public services whereas InstitutRL is among other things concerned with the extent to which agents have confidence in and abide by the rules of society [46]. Some countries had negative values for Aid and $K$ variables. For Aid, possible explanation is that countries were paying back more than they were receiving whereas for $K$, FDI outflows exceeded inflows.

\section{Results and Discussions}

For simplicity, all results are compiled according to each equation.

\subsection{Human Development Equation Results}

Main results for the human development equation are presented in Table 2 in the second column. Both SSACs' trade openness towards China and SSACs trade openness towards the rest of world had positive and significant impacts on hu- 
man development at $1 \%$ level. Thus, an increase in trade integration is expected to bring about positive improvements in terms of human development. Both variables for innovation from China and innovation from rest of world had negative and insignificant coefficients suggesting the need for more structure reforms on the part of SSACs and the need to adopt and adapt innovation from other countries such as China for industrial upgrading which will eventually lead to significant improvements in human development. Government effectiveness as a proxy for institutions for the human development equation had a negative and significant coefficient at $1 \%$ level also calling for more reforms. Education indicator also had a negative and significant coefficient at $1 \%$ level suggesting more reforms for the education policies to be linked towards human development. Government expenditure on health and economic growth both had positive and significant coefficients at $1 \%$ level suggesting that enhancement in these variables enhanced human development during the period under study.

Table 1. Summary statistics.

\begin{tabular}{|c|c|c|c|c|c|}
\hline & $(1)$ & (2) & (3) & (4) & (5) \\
\hline VARIABLES & $\mathrm{N}$ & mean & sd & $\min$ & $\max$ \\
\hline Education & 720 & 56.65 & 21.33 & 44.04 & 100 \\
\hline LandL & 720 & 0.350 & 0.477 & 0 & 1 \\
\hline FOCAC & 720 & 0.871 & 0.336 & 0 & 1 \\
\hline GDP current & 720 & 26,268 & 69,256 & 63.39 & 568,499 \\
\hline$H D I$ & 720 & 0.480 & 0.111 & 0.255 & 0.785 \\
\hline Exports & 720 & 7486 & 18,512 & 38.6 & 144,917 \\
\hline Imports & 720 & 7992 & 16,541 & 138.4 & 123,558 \\
\hline Exports to China & 720 & 2877 & 5660 & 0.000096 & 33,561 \\
\hline Imports from China & 720 & 1761 & 3425 & 0.342 & 16,006 \\
\hline Health & 720 & 7.512 & 2.310 & 1.446 & 16.11 \\
\hline$H C$ & 720 & 41.59 & 21.79 & 6.112 & 104.7 \\
\hline InstitGF & 720 & -0.648 & 0.585 & -1.884 & 1.049 \\
\hline Capital imports from China & 720 & 226.7 & 822.0 & 0.000055 & 7339 \\
\hline World capital imports & 720 & 1385 & 3794 & 0.286 & 30,424 \\
\hline Capital exports to China & 720 & 4.038 & 28.88 & 0.000012 & 660.9 \\
\hline World capital exports & 720 & 318.3 & 1627 & 0.000141 & 15,335 \\
\hline$K$ & 720 & 5.057 & 8.894 & -6.057 & 103.3 \\
\hline Growth & 720 & 12.81 & 18.30 & 1.229 & 116.5 \\
\hline Aid & 720 & 9.49 & 10.05 & -0.260 & 92.14 \\
\hline InstitutRL & 720 & -0.596 & 0.628 & -2.009 & 1.077 \\
\hline $\mathrm{L}$ & 720 & 7.509 & 10.16 & 0.0430 & 59.03 \\
\hline
\end{tabular}

Source: Authors calculations. 
Table 2. Human development equation results.

\begin{tabular}{|c|c|c|c|}
\hline & $(H D I)$ & $(H D I)$ & $(H D I)$ \\
\hline VARIABLES & GMM & 3SLS & GMM \\
\hline \multirow[t]{2}{*}{ AChinainnov } & -0.00226 & -0.00232 & \\
\hline & $(0.00183)$ & $(0.00183)$ & \\
\hline \multirow[t]{2}{*}{ ARInnov } & -0.00145 & -0.00246 & \\
\hline & $(0.00383)$ & $(0.00399)$ & \\
\hline \multirow[t]{2}{*}{ TORow } & $0.0242^{\star * \star}$ & $0.0257^{\star * *}$ & $0.0669^{* * *}$ \\
\hline & $(0.00429)$ & $(0.00460)$ & $(0.00507)$ \\
\hline \multirow[t]{2}{*}{ TOChina } & $0.00327^{* * *}$ & $0.00334^{* * *}$ & \\
\hline & $(0.000722)$ & $(0.000728)$ & \\
\hline \multirow[t]{2}{*}{ InstitGF } & $-0.00207^{\star * \star}$ & $-0.00222^{* * *}$ & 0.000123 \\
\hline & $(0.000524)$ & $(0.000436)$ & $(0.000788)$ \\
\hline \multirow[t]{2}{*}{ Education } & $-0.00668^{* * *}$ & $-0.00747^{* * *}$ & 0.000782 \\
\hline & $(0.00190)$ & $(0.00188)$ & $(0.00263)$ \\
\hline \multirow[t]{2}{*}{ Health } & $0.0195^{\star * *}$ & $0.0180^{\star * *}$ & $0.0378^{\star * \star}$ \\
\hline & $(0.00617)$ & $(0.00499)$ & $(0.00805)$ \\
\hline \multirow[t]{2}{*}{ Growth } & $0.0938^{\star * *}$ & $0.0726^{* * *}$ & $0.153^{* * *}$ \\
\hline & $(0.0105)$ & $(0.0244)$ & $(0.0227)$ \\
\hline \multirow[t]{2}{*}{ TAChinainnov } & & & -0.000542 \\
\hline & & & $(0.000553)$ \\
\hline \multirow[t]{2}{*}{ TARInnov } & & & $-0.0121^{* * *}$ \\
\hline & & & $(0.00320)$ \\
\hline \multirow[t]{2}{*}{ AChina } & & & -0.009035 \\
\hline & & & $(0.000476)$ \\
\hline \multirow[t]{2}{*}{ Constant } & $0.696^{* * *}$ & $0.893^{* * *}$ & $-0.583^{\star *}$ \\
\hline & $(0.114)$ & $(0.224)$ & $(0.244)$ \\
\hline Observations & 720 & 720 & 1120 \\
\hline
\end{tabular}

Source: The author's estimates. Note: ${ }^{* *},{ }^{* *}$ and ${ }^{*}$ denote respectively statistical significance at $1 \%, 5 \%$ and $10 \%$ levels. Robust standard errors in parentheses for simultaneous equation GMM. Traditional 3SLS assumes homoscedasticity and hence standard errors are not robust, however, robust standard errors can be estimated using multiple equation GMM. Country and year fixed effects are included for all equations.

\subsection{Economic Growth Equation Results}

Table 3 column 2 presents main results from two simultaneous equation GMM. SSACs trade openness towards China had negative and insignificant coefficient calling for more trade reforms to be growth enhancing. As expected SSACs trade openness towards rest of world had positive and significant impacts at $10 \%$ level suggesting that trade towards rest of world was growth enhancing. Human de- 
velopment indicator and FDI as proxy of physical capital both had positive impacts on economic growth at $1 \%$ level suggesting that improvements in these variables positively affected economic growth. Institutions proxied by rule of law and secondary school enrollment as proxy for human capital had negative and insignificant coefficients. SSACs need to strategize in order to improve on institution quality especially by reforming the prevailing institutions to be more inclusive. While for secondary school enrollment to be growth enhancing, there is need to re-align it with economic growth policies. Labor proxied as total working labor had negative and significant coefficient suggesting more reforms in labor and employment policies to be pro-growth. The study also found aid to be negative and significant coefficients both at $1 \%$ level. This call for more reforms as well, mostly on the complimentary and supporting policies if aid is to have meaningful impacts on economic growth. Landlocked variable as expected had negative and significant impacts at $1 \%$ level suggesting that landlocked SSACs face high transport costs which in turn affect their economic growth negatively. Innovation from China had positive and insignificant impacts on economic growth suggesting that increase in capital imports from China is growth enhancing. Whereas innovation from rest of world had negative and significant impacts at $1 \%$ level suggesting the need for more reforms by SSACs to effectively adopt and adapt innovation from other countries (Table 3 ).

\section{Robustness Checks}

As a robust check, the two simultaneous equation system was estimated using the 3SLS method. Comparable results were found with those from multiple equation GMM. The third column of Table 2 presents the results 3SLS for the human development equation which were very comparable with those obtained using GMM. Table 3 column 3 presents results from 3SLS for the economic growth equation. Secondary school enrollment as a proxy for human capital was found to be positive but insignificant, different from GMM results. SSACs trade openness towards rest of the world was no longer significant and became negative while SSACs trade openness towards China still was negative but now became significant at $5 \%$ level. The rest of the other variables were very comparable with the main results from simultaneous equation GMM. Single equations two-step estimations were conducted for both the economic growth and human development equation. The results were very comparable with those for the multiple equation GMM and were not included in this research.

Another robust check conducted involved two steps. In the first step, the length of the data set was extended from 1990 to 2017. In the second step, instead of only focusing on imports of capital goods as a measure of innovation from either China and rest of world, this time, total capital trade was used as a summation of capital exports and imports by respective SSACs as a ratio of their GDP, for either China and rest of the world. Estimation was conducted using simultaneous equation GMM. In the fourth column of Table 2 are results for the 
Table 3. Economic growth equation results

\begin{tabular}{|c|c|c|c|}
\hline & (Growth) & (Growth) & (Growth) \\
\hline VARIABLES & GMM & 3 SLS & GMM \\
\hline \multirow[t]{2}{*}{$H C$} & -0.0335 & 0.0182 & 0.00856 \\
\hline & $(0.0239)$ & $(0.0536)$ & $(0.104)$ \\
\hline \multirow[t]{2}{*}{$H D I$} & $1.315^{\star * \star}$ & $2.925^{\star \star *}$ & 0.0481 \\
\hline & $(0.121)$ & $(0.654)$ & $(0.814)$ \\
\hline \multirow[t]{2}{*}{$K$} & $0.0114^{\star * *}$ & $0.0107^{\star * *}$ & $0.0153^{\star *}$ \\
\hline & $(0.00344)$ & $(0.00368)$ & $(0.00649)$ \\
\hline \multirow[t]{2}{*}{ InstitutRL } & -0.00595 & -0.00705 & -0.00153 \\
\hline & $(0.00480)$ & $(0.00485)$ & $(0.00467)$ \\
\hline \multirow[t]{2}{*}{$L$} & $-0.320^{* * *}$ & -0.204 & $0.673^{*}$ \\
\hline & $(0.0782)$ & $(0.132)$ & $(0.362)$ \\
\hline \multirow[t]{2}{*}{ Aid } & $-0.0666^{* * *}$ & $-0.0563^{\star * \star}$ & $-0.135^{\star * *}$ \\
\hline & $(0.00639)$ & $(0.00713)$ & $(0.0107)$ \\
\hline \multirow[t]{2}{*}{ LandL } & $-1.308^{\star * *}$ & $-1.378^{\star \star \star}$ & $-0.488^{\star * *}$ \\
\hline & $(0.0577)$ & $(0.0669)$ & $(0.180)$ \\
\hline \multirow[t]{2}{*}{ AChinainnov } & 0.00241 & 0.00955 & \\
\hline & $(0.00557)$ & $(0.00738)$ & \\
\hline \multirow[t]{2}{*}{ ARInnov } & $-0.0436^{\star * *}$ & $-0.0339^{\star \star}$ & \\
\hline & $(0.0117)$ & $(0.0156)$ & \\
\hline \multirow[t]{2}{*}{ TORow } & $0.0246^{*}$ & -0.0258 & 0.0397 \\
\hline & $(0.0141)$ & $(0.0230)$ & $(0.0537)$ \\
\hline \multirow[t]{2}{*}{ TOChina } & -0.00196 & $-0.00633^{\star *}$ & \\
\hline & $(0.00215)$ & $(0.00290)$ & \\
\hline \multirow[t]{2}{*}{ TAChinainnov } & & & $0.00244^{\star}$ \\
\hline & & & $(0.00139)$ \\
\hline \multirow[t]{2}{*}{ TARInnov } & & & $-0.0385^{\star *}$ \\
\hline & & & $(0.0156)$ \\
\hline \multirow[t]{2}{*}{ AChina } & & & $-0.00226^{*}$ \\
\hline & & & $(0.00126)$ \\
\hline \multirow[t]{2}{*}{ Constant } & $12.69^{\star * *}$ & $8.267^{\star * *}$ & -0.879 \\
\hline & $(1.215)$ & $(1.373)$ & $(5.040)$ \\
\hline Observations & 720 & 720 & 1120 \\
\hline
\end{tabular}

Source: The author's estimates. Note: ${ }^{* *},{ }^{* *}$ and ${ }^{*}$ denote respectively statistical significance at $1 \%, 5 \%$ and $10 \%$ levels. Robust standard errors in parentheses for simultaneous equation GMM. Traditional 3SLS assumes homoscedasticity and hence standard errors are not robust, however, robust standard errors can be estimated using multiple equation GMM. Country and year fixed effects are included for all equations. 
human development equation using total capital trade as proxy for innovation. The only changes observed are on institution and education variables suggesting that there has been an improvement in these variables in SSACs from the 1990s. Table 3 column 4 presents results from economic growth equation. Human capital and human development variables were both positive but insignificant. FDI became significant now at 5\% level from $10 \%$ level. Labor became positive and significant at $10 \%$ level from being negative and significant at $1 \%$ level. SSACs trade openness towards rest of the world was positive and insignificant from being negative and insignificant at $10 \%$ level. China innovation was positive and now significant at $10 \%$ level whereas world innovation was still negative and significant but now at $5 \%$ level. SSACs trade openness towards China still was negative but now significant at $10 \%$ level.

\section{Conclusions}

This research examined the impact of trade by destination on human development paying particular attention on innovation channel. The research was demonstrated in FOCAC framework while controlling for other strategic partnerships using rest of world variable. Though the study focused on innovation, it controlled for endogenous impacts originating from economic growth by examining the framework using multiple equation GMM. The results indicated that both SSACs trade openness towards China and SSACs trade openness towards rest of world, had positive and significant impacts on human development at $1 \%$ level. The study also found that innovation from China and innovation from rest of world had both negative and insignificant impacts on human development.

Trade provides an opportunity for innovation through imports of capital goods which may be adapted to local needs hence providing the foundation for sustainable economic growth and human development. The results suggest that SSACs need to undertake reforms and invest more in education, technology and research so that they build the capacity to adopt and adapt foreign innovation from other countries while at the same time pursuing and enhancing trade integration with key strategic partnerships. There is need for national commitment to research and development activities and the expansion of the country's research capacity. Much as it is common to measure country's capacity using expenditure in research and development or number of technical and scientific journal publication, these data were not available for majority of countries in this research. Future studies may focus on the determinants of innovation in SSACs. Finally, this study recommends SSACs to tap into global innovation and adapt it to their domestic needs while at the same time making sure that the environment is conducive. Innovation adoption and adaptation requires supporting institutions, infrastructure, and human capacity.

\section{Conflicts of Interest}

The authors declare no conflicts of interest regarding the publication of this paper. 


\section{References}

[1] McCulloch, N., Winters, L.A. and Cirera, X. (2001) Trade Liberalization and Poverty: A Handbook. The Centre for Economic Policy Research, London.

[2] Nafziger, E.W. (2006) Economic Development. 4th Edition, Cambridge University Press, New York.

[3] UNDP Trade and Development Unit (2011) Trade and Human Development: A Practical Guide to Mainstreaming Trade. UNDP, Geneva.

[4] Samuelson, P.A. (1938) Welfare Economics and International Trade. The American Economic Review, 28, 261-266.

[5] Samuelson, P.A. (1962) The Gains from International Trade Once Again. The Economic Journal, 72, 820-829. https://doi.org/10.2307/2228353

[6] Khandelwa, A.K. and Faigelbaum, P.D. (2016) Measuring the Unequal Gains from Trade. Quarterly Journal of Economics, 1113-1180.

https://doi.org/10.1093/qje/qjw013

[7] Acemoglu, D., Johnson, S. and Robinson, J. (2001) The Colonial Origins of Comparative Development: An Empirical Investigation. American Economic Review, 91, 1369-1401. https://doi.org/10.1257/aer.91.5.1369

[8] Acemoglu, D., Johnson, S. and Robinson, J. (2002) Reversal of Fortunes: Geography and Institutions in the Making of the Modern World Income Distribution. Quarterly Journal of Economics, 117, 1231-1294. https://doi.org/10.1162/003355302320935025

[9] Lind, N. and Ramondo, N. (2018) Innovation, Knowledge Diffusion, and Globalization. NBER Working Paper 25071, NBER, Cambridge.

[10] Xavier, C. and William, F.M. (2017) The Innovation Paradox: Developing Country Capabilities and the Unrealized Promise of Technological Catch-Up. IBRD/World Bank, Washington DC.

[11] Howitt, P. (2009) Competition, Innovation and Growth: Theory, Evidence and Policy Challenges. In: Chandra, V., Eröcal, D., Padoan, P.C. and Braga, C.A., Eds., Innovation and Growth: Chasing a Moving Frontier, World Bank and OECD, Paris, 11-24.

[12] OECD (2015) The Innovation Imperative: Contributing to Productivity, Growth and Well-Being. OECD Publishing, Paris.

[13] World Bank (2010) Innovation Policy: A Guide for Developing Countries. Word Bank, Washington DC.

[14] Mullings, R. and Mahabir, A. (2018) Growth by Destination: The Role of Trade in Africa's Recent Growth Episode. World Development, 102, 243-261. https://doi.org/10.1016/j.worlddev.2017.10.009

[15] Frankel, J. and Romer, P. (1999) Does Trade Cause Growth? American Economic Review, 89, 379-399. https://doi.org/10.1257/aer.89.3.379

[16] Ortega, F. and Peri, G. (2014) Openness and Income: The Roles of Trade and Migration. Journal of International Economics, 92, 231-251. https://doi.org/10.1016/j.jinteco.2013.11.008

[17] Rodrik, D. and Rodríguez, F. (2001) Trade Policy and Economic Growth: A Skeptic's Guide to the Cross-National Evidence. In: Bernanke, B. and Rogoff, K.S., Eds., Macroeconomics Annual 2000, MIT Press, Cambridge, 261-338. https://doi.org/10.2307/3585399

[18] David, H.L. (2008) So You Want to Use a Measure of Openness? In: Banaian, K. 
and Roberts, B., Eds., The Design and Use of Political Economy Indicators, Palgrave Macmillan, New York, 15-32. https://doi.org/10.1057/9780230616622_2

[19] Otenia, T. (2017) Chinese Zero-Tariff Treatment for Least Developed Countries: China's Soft-Power in Action in Africa. Journal of International and Public Affairs, 1, 39-46.

[20] Oyejide, A.T., Bankole, A.S. and Adewuyi, A.O. (2009) China-Africa Trade Relations: Insights from AERC Scoping Studies. The European Journal of Development Research, 21, 485-505. https://doi.org/10.1057/ejdr.2009.28

[21] FOCAC (2000) Beijing Declaration of the Forum on China-Africa Cooperation. https://www.focac.org/eng/zywx_1/zywj/t606796.htm

[22] FOCAC (2018) Forum on China-Africa Cooperation Beijing Action Plan (2019-2021). https://www.focac.org/eng/zywx_1/zywj/t1594297.htm

[23] UNDP China (2013) South-South Cooperation: China-Africa Trade and Investment Cooperation Issue No 2. UNDP China, Beijing.

[24] China State Council (CSC) (2013) China-Africa Economic and Trade Cooperation. http://english.gov.cn/archive/white_paper/2014/08/23/content_281474982986536.htm

[25] National Bureau of Statistics of China (NBSC) (2016) China Statistical Year Book. http://www.stats.gov.cn/tjsj/ndsj/2016/indexeh.htm

[26] FOCAC (2015) The Forum on China-Africa Cooperation Johannesburg Action Plan (2016-2018). https://www.focac.org/eng/zywx_1/zywj/t1327961.htm

[27] World Bank (2019) World Development Report 2019: The Changing Nature of Work. World Bank, Washington DC.

[28] UNECA (2018) Towards Achieving the African Union's Recommendation of Expenditure of $1 \%$ of GDP on Research and Development. UNECA Policy Brief No. ECA/18/004, ECA Press, Addis Ababa.

[29] Hogan, M. and Gallaher, M. (2018) Quantitative Indicators for Country-Level Innovation Ecosystems. RTI Press Publication No. OP-0051-1805. Research Triangle Park, RTI Press, North Carolina. https://doi.org/10.3768/rtipress.2018.op.0051.1805

[30] World Bank (2018) World Development Report 2018: Learning to Realize Education's Promise. World Bank, Washington DC.

[31] Mustafaa, G., Rizovb, M. and Kernohanc, D. (2017) Growth, Human Development, and Trade: The Asian Experience. Economic Modelling Journal, 61, 93-101. https://doi.org/10.1016/j.econmod.2016.12.007

[32] Asongu, S. (2012) Globalization and Africa: Implications for Human Development. International Journal of Development Issues, 12, 213-238. https://doi.org/10.2139/ssrn.2493238

[33] Davies, A. and Quinlivan, G. (2006) A Panel Data Analysis on the Impact of Trade on Human Development. Journal of Socio-Economics, 35, 868-876. https://doi.org/10.1016/j.socec.2005.11.048

[34] Eusufzai, Z. (1996) Openness, Economic Growth, and Development: Some Further Results. The University of Chicago Press, 44, 333-338.

https://doi.org/10.1086/452216

[35] Nourzard, F. and Powell, J.J. (2003) Openness, Growth, and Development: Evidence from a Panel of Developing Countries. Scientific Journal of Administrative Development, 1, 72-94.

[36] Ram, D. and Peneva, R. (2012) Trade Policy and Human Development: A Cross-Country Perspective. International Journal of Social Economics, 40, 51-67. 
https://doi.org/10.1108/03068291311283436

[37] Kabadayi, B. (2013) Human Development and Trade Openness: A Case on Developing Countries. Advances in Management and Applied Economics, 3, 193-199.

[38] Chang, R., Kaltani, L. and Loayza, N.V. (2009) Openness Can Be Good for Growth: The Role of Policy Complementarities. Journal of Development Economics, 90, 33-49. https://doi.org/10.1016/j.jdeveco.2008.06.011

[39] Cosbey, A. (2004) A Capabilities Approach to Trade and Sustainable Development Using Sen's Conception of Development to Re-Examine the Debates. International Institute for Sustainable Development, Manitoba.

[40] UNDP (1990) Human Development Report. UNDP Press, Geneva.

[41] Sen, A. (1999) Development as Freedom. Oxford University Press, Oxford.

[42] Durlauf, S.N., Johnson, P.A. and Temple, J.W.R. (2005) Growth Econometrics, In: Aghion, P. and Durlauf, S.N., Eds., Handbook of Economic Growth, Vol. 1, Elsevier, Amsterdam, 555-677. https://doi.org/10.1016/S1574-0684(05)01008-7

[43] Greene, W.H. (2012) Econometric Analysis. 7th Edition, Prentice Hall, New York.

[44] Wooldridge, J.M. (2010) Econometric Analysis of Cross Section and Panel Data. 2nd Edition, MIT Press, Cambridge.

[45] UNDP (2018) Human Development Indices and Indicators: 2018 Statistical Update. UNDP, New York.

[46] Kaufmann, D., Kraay, A. and Mastruzzi, M. (2010) The Worldwide Governance Indicators: A Summary of Methodology, Data and Analytical Issues. World Bank Policy Research Working Paper No. 5430. 


\section{Appendix}

\section{List of Countries Used}

\begin{tabular}{|c|c|}
\hline 1) & Angola \\
\hline 2) & Benin \\
\hline 3) & Botswana \\
\hline 4) & Burkina Faso \\
\hline 5) & Burundi \\
\hline 6) & Cabo Verde \\
\hline 7) & Cameroon \\
\hline 8) & Central African Republic \\
\hline 9) & Congo, Dem. Rep. \\
\hline 10) & Cote d'Ivoire \\
\hline 11) & Equatorial Guinea \\
\hline 12) & Ethiopia \\
\hline 13) & Gabon \\
\hline 14) & Gambia, The \\
\hline 15) & Ghana \\
\hline 16) & Guinea \\
\hline 17) & Kenya \\
\hline 18) & Lesotho \\
\hline 19) & Liberia \\
\hline 20) & Madagascar \\
\hline 21) & Malawi \\
\hline 22) & Mali \\
\hline 23) & Mauritania \\
\hline 24) & Mauritius \\
\hline 25) & Mozambique \\
\hline 26) & Namibia \\
\hline 27) & Niger \\
\hline 28) & Nigeria \\
\hline 29) & Rwanda \\
\hline 30) & Sao Tome and Principe \\
\hline 31) & Senegal \\
\hline 32) & Seychelles \\
\hline 33) & Sierra Leone \\
\hline 34) & South Africa \\
\hline 35) & eSwatini \\
\hline 36) & Tanzania \\
\hline 37) & Togo \\
\hline 38) & Uganda \\
\hline 39) & Zambia \\
\hline 40) & Zimbabwe \\
\hline
\end{tabular}

